\title{
EFL Learners' Perceptions on ZOOM Application in the Online Classes
}

\author{
NADILA NURAZIZA \\ Universitas Teknokrat Indonesia \\ nadilaziza24@gmail.com \\ LULUD OKTAVIANI \\ Universitas Teknokrat Indonesia \\ lulud_oktaviani@teknokrat.ac.id \\ FATIMAH MULYA SARI \\ Universitas Teknokrat Indonesia \\ fatimah@teknokrat.ac.id
}

\begin{abstract}
Pandemic Covid-19 brings impactful aspects for several sectors, especially in the education sector. The teaching and learning process has shifted to online learning. It challenges the teachers as well as the students to fully support the success of the online classes. Teachers are required to be more creative in delivering the learning materials for their students. Meanwhile, students are encouraged to be autonomous learners. This paper, therefore, aims to investigate the students' perceptions toward the implementation of the ZOOM application to support the online learning process and explore how this application gives a new shape in the educational industry. The qualitative approach was chosen for this study. The data were obtained from questionnaires and interviews. The findings showed that there were some perceptions about the implementation of ZOOM to support online learning. Most of the students thought implementation of elearning should be improved continuously. Surprisingly, it gave significant changes toward the learning and teaching process, especially during covid-19itself.
\end{abstract}

Keywords: education; zoom application; e-learning implementation

\section{INTRODUCTION}

Nowadays, technology has entered many aspects of life, for example economy, industry, tourism, and education. We are familiar to the role of technology in education aspect. Teachers are required to be professional in implementing technology in learning and teaching process. Their creative and innovative ideas become the key of successful learning in using digital tools. The use of digital media in learning is expected to be able to enhance students' motivation in learning. Learning process has changed significantly, but the aims of it will never change. Learning process that held in school mostly using teacher centered but starting from 1971, it was changed to students centered. 
It was happened because of the impact from globalization era. The improvement of internet usage also be one of the reasons why learning process changed its system.

This year becomes the year which has changed anything, especially in education sector. Teacher and students are forced to boost their knowledge in using technology. Previously learning process was conducted in the form of blended learning. Blended learning is a process of learning in two ways or we can define it as combination between online learning and face to face lectures. Online learning is the learning process held using technology, like some application to transfer knowledge to the students everywhere because it can reach people wherever they are. Teacher and students now are not doing the learning process face to face but it has shifted to online classes which teacher and students doing their learning in distance.

This year becomes the gate of implementation of full online learning in many areas. It is supported by some applications to conduct e-learning such us Google meet, Google classroom, ZOOM and etc.ZOOM has entered to support online learning and it has also implemented in some schools in Indonesia, especially in Lampung. This is one the applications that support online classes. Teachers may create a class to conduct online learning. Online classes conducted via ZOOM become the choice of teachers when they are conducting class to directly handle their students. Many ways of teaching can be implemented via ZOOM because teachers and students can easily discuss the topic that is being discussed. Teachers and students are given a freedom to access it wherever and whenever they want so that it helps them in conducting the online learning. Learning process cannot be separated from the role of teachers and students.

Many studies have examined the role of technology-driven media for language learning. Brahma (2020), for example, investigated the use of zoom as media to conduct e-learning. Fauziah (2021) dicovered students' perception and motivation on online learning trough Zoom. Vitoria, Mislinawati, \& Nurmasyitah (2018) looked at university students' perception of e-learning through a web-based module. They found that many users of internet especially for the usage of online learning thought it was easy to be used and can improve their understanding about the subject. This study, therefore, wants to look at the perception of students toward the implementation of online learning especially the perception of EFL students toward online classes conducted via ZOOM application.

\section{LITERATURE REVIEW}

Internet users in Indonesia is developing day by day. Jatmiko (2020) as cited in Harahap and Adeni (2020) stated that internet users are expanding. In the year 2020 to the second quarter, internet users come to 196.7 million or 73.7 of population. It is supported by the fact that in 2020 , teachers and students in all over Indonesia are doing their learning process via some applications so that it will impact to the internet users. Since the government issue policy to do learning process from home to cut the spread of corona virus or Covid-19, there are many applications to support elearning that can be used. Consequently, the usage of application to support online learning increase, the highest usage of it is in the first week of the implementation of the policy itself.

ZOOM as one of the applications that support online learning now become well known, many teachers use ZOOM to interact directly with their students. The usage of ZOOM in education field usually for doing the presentation or speaking subject so that teachers and students may discuss directly without gathering in the class. It helps them in conducting the meeting. But in fact, 
conducting the online learning may cause the new phenomenon among teachers and also the students. Both teachers and students are struggling to do the online classes. Teachers are struggling with the idea to cover the subject to be interesting for the students and the students are fighting with its new technique of teaching. To build a better learning process, teachers need to master all the features of ZOOM application so that learning can be as active as in the class.

There are some features in ZOOM application that can support learning activity like microphone, room chat, raise hand, applause, and etc. It supports the speaking class to conduct the learning activity. Teachers may ask their students to be more active in following the class activity by asking questions. Teachers also may have a small activity to boost students' spirit when they are following the activity by conducting a quiz so that students are competing to raise their virtual hand in ZOOM features and other students may use applause feature to appreciate their friends answer toward the quiz given by the teacher. Taking the advantage of its features may help teachers build a good interaction to their students. ZOOM is a good choice to implement in speaking subject cause through ZOOM the teachers may directly connect with their students in various areas. This strategy is good enough to be implemented to students to make learning activity be more interesting and active. This present study aims to look closer at EFL students' perception of the ZOOM usage to support online learning. The result may be taken for the teachers to conduct online learning via ZOOM. The teachers also may take a guidance from this study to learn the new style of teaching in online classes.

Studies about online learning have been done extensively. For instance, Fauziah (2021) investigated high school students' perception and motivation in e-learning through Zoom, and found that the students had positive and negative perceptions in using this application in e-learning especially in the English subject. Some of students understood the explanation when the teacher explained using gesture while it was a negative perception for some students when they had a bad internet connection which made the explanation unclear.

Alfadda and Mahdi (2021) measured students' use of Zoom application. They found that there was a solid positive relationship between the actual use of Zoom and the students' attitudes and behavioral purposeful. In addition, there was a positive relationship between computer self-eficacy and the other variables of the study. Rahayu(2020) conducted a study related to the use of Zoom as media to conduct e-learning. In this study, Rahayu (2020) discovered more than $60 \%$ students had positive view to synchronous e-learning, in this case, Zoom application. But more than $60 \%$ students also agreed that the material and the access to the lesson was better in the offline learning. Finally, the study reported in this present article examined the same issue about students' perception on Zoom when it is implemented in their online classes, but it focused on higher education students in one of the university in Bandar Lampung.

\section{METHOD}

This study used a qualitative descriptive approach. Shank (2002) defines that a qualitative research as a form of systematic empirical inquiry into meaning. Denzin and Lincoln (2002) describe qualitative research as involving an interpretative and naturalistic approach. The data was collected for this research by distributing questionnaire through Google Form. This study was conducted in a university in Bandar Lampung, involving students majoring in the English Education Study Program in 2018 until 2019 batch as the sample of the study. There were 45 students from 2019 
batch and 42 students from 2018 batch and the total was 87 students, but only 25 students who filled out the questionnaire. The reason why the researchers chose them because they were still having speaking class conducted online and they were using Zoom as a media to conduct the elearning. Besides, the researchers interviewed the EFL students to know how deep ZOOM application shape their learning style.

The questionnaire in Google Form used multiple choice format, which are A (Totally Agree), B (Agree), C (Disagree), and D (Totally Disagree). At the end of the questionnaire, the researchers added the question about opinion. There were 11 (eleven) multiple choice questions and 1 (one) essay question in Google Form. These are the questions:

1. Do you know Zoom?

2. Do you like Zoom as a media to support e-learning?

3. Do you really enjoy the learning process through Zoom?

4. When Zoom is implemented, do you think your learning felt better?

5. Does Zoom can affect you learning?

6. Do the features of Zoom application are easy to be understood?

7. Based on your opinion, is Zoom the best choice to be implemented in your school?

8. I think that Zoom is easier than other platform.

9. I found that Zoom is not effective to be used to support e-learning.

10. I feel that learning via Zoom make me bored.

11. I found difficulties in learning via Zoom.

12. Should the implementation of Zoom be improved? Why?

\section{FINDINGS AND DISCUSSION}

This part presents the findings and the discussion. Data were collected from Google Form. The research discusses how this application bring impact and new thing in teaching and learning process. The questionnaires were divided into 3 part, first some question related to them, second about the statement and the last their opinion toward the implementation.

\begin{tabular}{cccc} 
& \multicolumn{3}{c}{ TABLE 1. Students' awareness of ZOOM application. } \\
\hline No & Question & Yes (\%) & No (\%) \\
\hline 1 & Do you know Zoom? & $100 \%$ & $0 \%$ \\
\hline
\end{tabular}

From the first result of questionnaire it is known that all of the participant who fill this questionnaire are familiar with ZOOM application. 
TABLE 2. Students' perceptions about ZOOM application.

\begin{tabular}{|c|c|c|c|c|c|}
\hline \multirow[b]{2}{*}{ No } & \multirow[b]{2}{*}{ Questions } & \multicolumn{4}{|c|}{ Answer (\%) } \\
\hline & & $\begin{array}{c}\text { Totally } \\
\text { Agree }\end{array}$ & Agree & Disagree & $\begin{array}{c}\text { Totally } \\
\text { Disagree }\end{array}$ \\
\hline 1. & $\begin{array}{l}\text { Do you like Zoom as a media to } \\
\text { support e-learning? }\end{array}$ & & $80 \%$ & $20 \%$ & \\
\hline 2. & $\begin{array}{l}\text { Do you really enjoy the learning } \\
\text { process through Zoom? }\end{array}$ & & $73,3 \%$ & $26,7 \%$ & \\
\hline 3. & $\begin{array}{l}\text { When Zoom is implemented, do } \\
\text { you think your learning felt } \\
\text { better? }\end{array}$ & $6,7 \%$ & $53,3 \%$ & $40 \%$ & \\
\hline 4. & $\begin{array}{l}\text { Does Zoom can affect you } \\
\text { learning? }\end{array}$ & & $80 \%$ & $20 \%$ & \\
\hline 5. & $\begin{array}{l}\text { Do the features of Zoom } \\
\text { application are easy to be } \\
\text { understood? }\end{array}$ & $20 \%$ & $53,3 \%$ & $26,7 \%$ & \\
\hline 6. & $\begin{array}{l}\text { Based on your opinion, is Zoom } \\
\text { the best choice to be } \\
\text { implemented in your school? }\end{array}$ & & $66,7 \%$ & $33,3 \%$ & \\
\hline 7. & $\begin{array}{l}\text { I think that Zoom is easier than } \\
\text { other platform. }\end{array}$ & & $66,7 \%$ & $33,3 \%$ & \\
\hline 8. & $\begin{array}{l}\text { I found that Zoom is not } \\
\text { effective to be used to support } \\
\text { e-learning. }\end{array}$ & & $33,3 \%$ & $66,7 \%$ & \\
\hline 9. & $\begin{array}{l}\text { I feel that learning via Zoom } \\
\text { make me bored }\end{array}$ & $6,7 \%$ & $46,7 \%$ & $40 \%$ & $6,7 \%$ \\
\hline 10. & $\begin{array}{l}\text { I found difficulties in learning } \\
\text { via Zoom. }\end{array}$ & & $53,3 \%$ & $40 \%$ & $6,7 \%$ \\
\hline
\end{tabular}

The table above shows that students who like ZOOM as media to support e-learning are about $80 \%$ agree, and the rest of them (20\%) do not like conducting e-learning through ZOOM application. The next question is about students feeling, to make sure that students enjoy online learning via ZOOM, the result showed that $73,3 \%$ of the participants agreed and $20 \%$ of participant disagree, it means that most of the students enjoyed meeting via ZOOM application. Third question is about the impact of the ZOOM implementation, with 6,7\% participant totally agree, 53,3\% participants agreed, $40 \%$ students disagree and $0 \%$ participant who totally disagree.

The other question asks whether or not ZOOM affect students learning. Surprisingly, $80 \%$ students agreed and $20 \%$ disagreed, which means that ZOOM may affect their learning process in some ways. The fifth question is about the features provided by ZOOM. The result showed that $20 \%$ students totally agreed, 53,3\% students agreed, 26,7\% disagreed, $0 \%$ totally disagreed that the features from ZOOM were easy to be understood. The next question is students' opinion about whether ZOOM is the best choice to be implemented in their school (University), and the result revealed that $66,7 \%$ students chose agree and $33,3 \%$ students disagreed, and $0 \%$ for totally agreed and disagreed. 
The seventh is statement, $66,7 \%$ of students who fill this questionnaire agree with the statement that ZOOM is easier than other platform, and 33,3\% disagree to this statement. There are $33,7 \%$ of students agree and $66,7 \%$ disagree that ZOOM is not effective to be used to support e-learning. Also, for about $6,7 \%$ of students said totally agree, $46,7 \%$ of students agree, $40 \%$ of students disagree and $6,7 \%$ students chose totally disagree about the statement that they feel bored when conducting the meeting via ZOOM. And the next statement, it showed that 53,3\% students agree and $40 \%$ students disagree and 6,7\% totally disagree about the statement that they found some difficulties in conducting the meeting via ZOOM application.

TABLE 3. Students' opinion about the implementation of ZOOM.

\begin{tabular}{|c|c|c|}
\hline NO & Question & Responses \\
\hline \multirow{4}{*}{1} & \multirow{4}{*}{$\begin{array}{l}\text { Should the Implementation of ZOOM be } \\
\text { improved? Why? }\end{array}$} & $\begin{array}{l}\text { Security experts say that using the Zoom } \\
\text { application should be extra careful. This } \\
\text { relates to security issues such as the absence } \\
\text { of end-to-end encryption. strong possibility } \\
\text { that our data will be hacked. } \\
\text { Yes, because when my connection is just a } \\
\text { little unstable I can't follow the meeting } \\
\text { smoothly } \\
\text { I think all the features in zoom application } \\
\text { are extremely good, it's very easy to } \\
\text { understand. }\end{array}$ \\
\hline & & too difficult \\
\hline & & $\begin{array}{l}\text { No, because learning via zoom take too } \\
\text { much quota and sometimes the internet } \\
\text { access is not stable on some area. }\end{array}$ \\
\hline & & $\begin{array}{l}\text { I think everything is good } \\
\text { Yes, it should be because to make it easier } \\
\text { to access and use it } \\
\text { Because zoom make many data internet } \\
\text { little lavish, so zoom has make upgrade the } \\
\text { application, and to upgrade the strong } \\
\text { signal, because if the signal low the } \\
\text { someone join can left } \\
\text { anyway the best zoom } \\
\text { Yes of course, because zoom has limited } \\
\text { time to use, and that's top short I guess. }\end{array}$ \\
\hline
\end{tabular}


Yes, since we conduct online learning, studying using pdf or powerpoint only isn't effective for me because sometimes the materials are hard to understand without explanation from the lecturer. I hope next semester the subjects that need more explanation will be conducted through ZOOM.

From the table above, we can conclude that many students agree that the implementation of ZOOM need to be improved, because some of them found the difficulties, like the security issues, too much internet quota needed, the limited time that ZOOM has to be access, and other problems.

\section{INTERVIEWING THE EFL STUDENTS}

Interview is one of the methods that can be used by researchers to dig further information from the informants. The researchers used this method to support the data that have been collected. The researchers conducted the interview with 2 students who come from 2019 batch and 2018 batch as the sample of the data. Student A for 2019 batch and B for 2019 batch. The result can be seen as follows.

\section{Q1 : Do you familiar with Zoom application?}

Student A \& B said "Yes, I do."

From this simple answer, we know that they have the same experience to know Zoom. This question indicates that both students will be able to answer the next questions.

\section{Q2 : What do you know from this application?}

Student A said that some point that she know about this application is a virtual communication media that is often used to facilitate learning and webinar. Student B said that "it is an application that used for online class" Both statements are correct instead of it is an application to conduct online class it also can be used as platform to communicate among people. Students still have a positive view toward this application. Not only that one of them also try to correlate to other function of Zoom.

\section{Q3 : Have you ever used this application for studying?}

Student A stated that her classmate and she often use this application to replace the traditional class which is face to face class. And students B also said agreed that in the speaking class of every meeting, her friends and she always uses this application to make it easier for them in the teaching and learning process, presentations and so on. 
It also supports the question number 1 that asked about do the students like conducting online class using Zoom and there were $80 \%$ of the students agreed to this. Until this stage, Zoom helps students and teacher to conduct e-learning.

\section{Q4 : What are the difficulties that you faced in implementing this app for speaking class?}

Student A and B mostly have the same obstacle when they use Zoom. The problem that often occur when they use this application are bad internet connection, quota usage. In addition, the first thing is that beginners who use this application find it difficult about the various menus in this application.

Zoom have some feature that can be used by the users. This actually aim to facilitate students and teachers in doing the learning and teaching process. But for some students it may bring a new hard thing for them.

\section{Q5 : So how do you usually solve this problem?}

Student A tried to solve the obstacle that she faced by going somewhere nearby her house. And for student B have different way to solve her problem in online class, she said that the first thing she did to solve this problem is to minimize any obstacles, for example when there is bad internet connection and wasteful of our quota usage, she can turn off the video and only the speaker turns it on. At least this way she can still join the class by listening and watching until it is finished.

There will always be problems when we implement a new thing. But we can not put those problems as a hard thing to solve. We have a lot of ways to solve it. Students have their own way in solving the problems even one student to another has different way and different problems.

\section{Q6 : Do you feel that this application brings a new shape to your learning process?}

Student B also said agree to the question given it is not easy to adapt this application to our learning process. But after she get to used it, in her opinion this application makes it easier for her to meet and talk without having to be in the same place. Wherever she is, she can do it with this application. A new thing entered to their learning process but as long it give a positive effect they feel it is not a big problem. In the other way, this application better than implemented to replace the traditional class.

Other student responded to this question. Student B thinks it can (bring a new shape to learning process). Until now, most of the time the lecturers only gave her pdf, ppt, or videos for us to read or watch, but she doesn't think that was effective because she could skip reading or watching those materials since no one would know. Whether she read or watch the materials given, it depends on our self-awareness, when she utilize ZOOM for conducting online learning, at least she have this responsibility to attend the class, and like it or not we must attend the class. That way, she can listen to the lecturer's explanation and gather some useful information

The findings found that $100 \%$ students who fill the questionnaire are familiar with ZOOM application. This means that the students and the teachers are familiar with using ZOOM, so it is not a new thing for them. The findings showed the good perception of students toward the implementation of ZOOM application to support the online learning. They think that the 
implementation of ZOOM can be the replacement of learning and teaching in the class because they can easily communicate and respond toward the explanation of the teachers.

The implementation of ZOOM application as media to support the online learning need to be improved from teacher's side, especially when the teachers give the materials to students. It can't be imagined when teachers only transfer their knowledge by implementing teachers' centered. A good strategy must be used to make teaching and learning process will not be bored, because the data collected from the questionnaire said that $46,7 \%$ of students feel that teaching and learning process via ZOOM make them bored so that it forces teachers' creativity to make an interesting material. Besides, ZOOM may help teachers in conducting the teaching and learning process to directly control their students like in the class. Brahma, I. A. (2020). stated that the teachers and the students are able to discussion and Q n A (Question and Answer) through online learning. ZOOM is a cloud-based video conferencing meeting, group messaging and secure session recording.

The usage of ZOOM application in teaching and learning process is effective to bring a new shape toward the implementation of online learning for most of students. According to Bunga (2020), "there is also a scheduling feature which is very useful for the teacher or students to make it easier to schedule meetings, so that meetings can be conducted in a more scheduled manner". It means that ZOOM only changes the teaching and learning system to become online. Teachers may also take many advantages of using this application like the features that can be used to support learning activity in order not to be passive classroom. ZOOM can be chosen for conducting online learning.

\section{CONCLUSION}

The researchers conducted this research to find out and to look closer about the perception of EFL students toward ZOOM implementation to support the online learning. The researchers draw it to get the answer of "Is this application bring the new shape of teaching and learning process?" to answer this question the researchers distribute the question through questionnaire and also by conducting the interview with EFL students.

Based on the findings, the researchers found that students feel that using ZOOM as media to conduct online learning may bring new shape, new colors for the learning process. It is proven that previously students only read powerpoint and watch videos given by the teachers and it is not effective to be implemented because we can easily skip reading and also watchZ the video without worrying of anything but if the learning process are conducted through video meeting conference, students have to prepare themselves to join and follow the class. At least students need to understand the material given by teacher to follow and get the score without trying to browse the answer.

Using ZOOM also is not difficult as the other media. ZOOM has made some features to be understood easily for both teachers and students. It helps them in using this application whenever they want although there are also many application or media that can be used for online teaching and learning process, such as Instagram usage conducted by Oktaviani and Desiarti (2016), Memrise usage conducted by Aminatun and Oktaviani (2019), Powtoon usage conducted by Oktaviani and Mandasari (2020), etc. 
Based on the data collected, some students said that using ZOOM can make them bored so that in using ZOOM application as media for online classes, teachers have to be creative in making the materials to be interesting, such us by using some features in ZOOM application. For example, by using one of the features like raise hand feature, teacher may ask the students to answer teacher's question by raising their hand. After that the one who raise his hand will be allowed to talk and answer the question given. When the answer is correct, other students may give applause by using feature reaction.

The last, findings also showed that EFL students have a good perception and responses toward the implementation of ZOOM in online classes. There re some recommendations for the EFL students, teachers and the future researchers who will conduct the similar issues. Firstly, Zoom application is esay to be used. Beside, the implementation should be maximized. So, it will be a good thing when the future researcher focus on the implementation from teachers perspective so that it will improve the quality of the learning and teaching process. Second, this study was conducted in higher education level and the main focus was EFL students who are familiar with the use of technology so that they may have a little problem on the implementation of this application. But, for the students in junior or senior high school, it will be another case when zoom is implemented.

There are still many students who think that using Zoom as media to conduct e-learning is not the best choice. For some of them this application consumed too much data, so teachers need to consider this thing before they conduct e-learning using Zoom. Based on the research, the EFL students are welcoming the implementation of ZOOM on the online classes and they expect that the implementation of ZOOM will be improved in some aspects and may be implemented not only in speaking class but also in some classes.

\section{REFERENCES}

Alfadda, H. A., \& Mahdi, H. S. (2021). Measuring Students' Use of Zoom Application in Language Course Based on the Technology Acceptance Model (TAM). Journal of Psycholinguistic Research, 1-18

Aminatun, D \& Oktaviani, L. (2019). Memrise: Promoting Students' Autonomous Learning Skill through Language Learning Application. Metathesis: Journal of English Language, Literature, and Teaching, 3(2): 214-223.

Brahma, I. A. (2020). Penggunaan zoom sebagai pembelajaran berbasis online dalam mata kuliah sosiologi dan antropologi pada mahasiswa PPKN di STKIP Kusumanegara Jakarta. Aksara: Jurnal Ilmu Pendidikan Nonformal, 6(2), 97-102.

Claudya, S, C. (2020, Mei 5). Efektivitas Zoom di Tenga Pandemi Corona sebagai Media Pembelajaran Jarak Jauh. [Web Page]. Retrieved from https://www.kompasiana.com/bunga99525/5eb16b85d541df4a36658ee2/efektivitas-zoom-di-tengahpandemi-corona-sebagai-media-pembelajaran-jarak-jauh

Denzin, N. K., \& Lincoln, Y. S. (2002). The qualitative inquiry reader.

Fauziah, N. (2021). Students'perception and motivation in English online learning through zoom apps (A descriptive qualitative study at the twelfth grade students of SMA Kartika III-I Banyubiru in Academic Year 2020/2021

Harahap, M. A., \& Adeni, S. (2020). Tren penggunaan media sosial selama pandemi di indonesia. Professional: Jurnal Komunikasi Dan Administrasi Publik, 7(2), 13-23.

Mahajan M V, Kalpana. R. (2018). A study of students' perception about e-learning. Indian J Clin Anat Physiol, 5(4), 501-507. 
Oktaviani, L. \& Desiarti, E. M. 2016. Instagram: A social media usage to create attractive advertisement for management students. Language in the Online \& Offline World 5: The Amplitude Proceedings, 305-309.

Oktaviani, L. \& Mandasari, B. 2020. Powtoon: A digital medium to optimize students' cultural presentation in ELT classroom. Teknosastik: Journal Bahasa dan Sastra, 18 (1), 33-41.

Ospina, S. (2004). Qualitative Research. Encylopedia of Leadership. hal. 1

Shanks, G. (2002). Guidelines for conducting positivist case study research in information systems. Australasian Journal of Information Systems, 10(1).

Stephanie J. \& Major, C. 2012. Students Experiences in Online Courses. The quarterly review of distance education, 13(2).

Sun, A \& Chen, X. (2016). Online Education and Its Effective Practise: A Research Review. Journal of Information Technology Education, 15.

Vitoria, L., Mislinawati, M., \& Nurmasyitah, N. (2018, September). Students' perceptions on the implementation of e-learning: Helpful or unhelpful?. In Journal of Physics: Conference Series (Vol. 1088, No. 1, p. 012058). IOP Publishing. 